Лестев А.Е.

\title{
ПОНИМАНИЕ МЕНТАЛЬНОСТИ СТРАНЫ - ЗНАЧИМЫЙ ФАКТОР В ВЫСТРАИВАНИИ ВНЕШНЕПОЛИТИЧЕСКИХ ОТНОШЕНИЙ (НА ПРИМЕРЕ ПОСЛЕВОЕННЫХ ОТНОШЕНИЙ МЕЖДУ СССР, США И ЯПОНИЕЙ)
}

\begin{abstract}
Аннотация. Предметом исследования являются послевоенные международные отношения между СССР, США и Японией. В частности, вопрос передачи императора Японии Хирохито под суд Международного военного трибунала за военные преступления. Вопрос о целесообразности наказания императора решался американским командованием на основании анализа специалистов, исходя из политических последствий этого шага для политики Соединенных итатов в отношении Японии. Вопрос о наказании императора являлся одним из ключевых противоречий между СССР и США в области послевоенного устройства Японии, став одним из катализаторов осложнения отношений между СССР и Японией. Исследование произведено на основании изучения исторических документов, свидетельств очевидцев событий, а также статей и научных работ ведущих специалистов в этой области. $B$ статье продемонстрировано, что американские специалисты прекрасно изучили ментальность японского народа, на основании чего сумели выработать успешную политику в отношении Японии и СССР. Используя в своих целях вопросы о наказании императора, о репатриации японских военнопленных, о территориальной принадлежности Курильских островов, США создало для СССР «японскую проблему», нерешенную до нашего времени.

Ключевые слова: Япония, Император Хирохито, Отношения США-СССР, Послевоенные отношения, Японские военные преступления, Вторая Мировая Война, Русско-японские отношения, Холодная война, Внешняя политика, Капитуляция Японии.

Review: The article focuses on the postwar relations between the Soviet Union, the USA and Japan, particularly, on the issue of extradition of the Emperor Hirohito to the International Military Tribunal for war crimes. The question of appropriateness of punishment was considered by American command on the base of the analysis of specialists and in terms of the political consequences of this step for the American policy towards Japan. The issue of the emperor prosecution was one of the main contradictions between the USSR and the USA in the sphere of a postwar order in Japan and served as one of catalysts of worsening of relations between the USSR and Japan. The research is based on the historical documents, the evidences of the witnesses of those events and the articles and scientific works of the leading specialists in this sphere. The author concludes that American specialists had a perfect understanding of the mentality of the Japanese and managed to choose a successful strategy in relation to Japan and the USSR. Using the issues of prosecution of the emperor, repatriation of Japanese prisoners of war, territorial belonging of the Kuril Islands, the USA created a "Japanese problem" for the USSR, which hasn't been solved yet.
\end{abstract}

Keywords: Russian-Japanese relations, WWII, Japan war crimes, Postwar relations, Relations USA-USSR, The Emperor Hirohito, Japan, Cold war, Foreign policy, capitulation of Japan.

3 авершающим аккордом Второй Мировой Войны стала капитуляция Японии, которая состоялась фактически 14 августа 1945 года после того как Император Хирохито обратился по радио к японскому народу с сообщением об окончательной капитуляции Японии и призывом сложить оружие. В результате этого обращения, за исключением редких случаев, около 7 миллионов японских солдат сложили оружие, а американские войска смогли осуществить оккупацию Японии практически без сопротивления [1]. Юридически капитуляция Японии была оформлена 2 сентября 1945 года после подписания акта о капитуляции.

После завершения войны основными вопросами и предметами политического торга в отношениях между СССР и США стали вопросы о репатриации военнопленных и о наказании военных преступников. Вопрос о наказании военных преступников напрямую был связан с личностью Императора Японии Хирохито. Еще до завершения войны целый ряд влиятельных американских политиков выступали за сохранение императорской системы власти в Японии после ее оккупации, сре- 
ди них были: бывший посол США в Японии, заместитель государственного секретаря Дж. Грю, военный министр Г. Стимсон, помощник президента адмирал У. Леги $[2$, с. 20]. В самой Японии вопрос о сохранении существующего строя оставался главным условием принятия условий Потсдамской декларации. Японское правительство, осознав бесперспективность продолжения войны, стремилось к её скорейшему окончанию отчасти из-за страха перед коммунистической революцией, о чем в своем докладе от 14 февраля 1945 г. писал принц Фумимаро Коноэ [2, с. 27]. Надо сказать, что вряд ли американские войска, которые в любом случае рано или поздно оккупировали бы Японию, позволили бы создать в Японии коммунистический строй.

После завершения войны послевоенное устройство Японии и все вопросы с этим связанные стали одной из сфер борьбы между США и СССР $[3$, с. 7].

В послевоенные годы фактическим главой Японии, ответственным, в том числе и за международные контакты, был генерал армии США Дуглас Макартур, именовавшийся главнокомандующим союзных держав в Японии. В документе «Основные принципы политики США в отношении Японии в начальный период оккупации», одобренном президентом США спустя 4 дня после капитуляции Японии, главнокомандующему предписывалось считаться, по возможности, с мнением других стран-союзниц, но было сказано, что «в случае каких-либо расхождений во взглядах между ними предпочтение будет отдаваться политике Соединенных штатов» $[4$, с. 498]. Для контроля за действиями главнокомандующего был создан Союзный совет для Японии из представителей четырех стран - СССР, США, Великобритании и Китая. На практике Совет также контролировался американцами: пост председателя занял заместитель главнокомандующего союзными войсками, начальник дипломатического отдела штаба Макартура Д. Ачесон [4, с. 499]. Из представителей 11 стран был сформирован Международный военный трибунал для суда над военными преступниками. Главным обвинителем Международного военного трибунала для Дальнего Востока был американский адвокат Джозеф Кинан [2, с. 68]. Таким образом, решение о привлечении к суду Международного военного трибунала японского императора зависело от решения США и в частности от главнокомандующего союзными войсками генерала Дугласа Макартура.
Генерал Макартур активно выступил против осуждения императора, о чем сообщил в Белый дом: «Обвинительный приговор императору приведет японское общество к глубочайшему эмоциональному потрясению, трагические отголоски которого ощутят и грядущие поколения страны» [2, с. 68]. Фактически это сообщение повторяет основной вывод, сделанный 2 октября 1945 г. в «Донесении главнокомандующему» [5] военным секретарем главнокомандующего, бригадным генералом Боннером Ф. Феллерсом. Именно Боннер Феллерс возглавил расследование штаба Макартура в отношении императора. В своем донесении Феллерс писал: «Если императора судить за военные преступления, правительственная структура рухнет и всеобщее восстание будет неизбежно. Народ безропотно снесет любое другое унижение. Хотя они разоружены, может возникнуть хаос и кровопролитие. Потребуется большой экспедиционный корпус со многими тысячами государственных служащих. Тогда период оккупации продлится, и мы оттолкнем от себя японцев» [5]. Таким образом, штаб генерала и сам генерал Макартур сформировали свою позицию по недопущению суда над императором Японии Хирохито. Несмотря на это никаких официальных заявлений по этому поводу не делалось до 17 июня 1946 года, когда Д. Кинан дал понять, что император к суду привлечен не будет. Фактически вопрос был решен, а сам Хирохито даже написал письмо президенту США Г. Трумэну с благодарностью за великодушное к нему отношение [2, с. 69].

Советское правительство, безусловно, знало о том, что решение по поводу судьбы императора Японии американцами уже принято: императора судить не будут. Тем более удивительным и провальным, с точки зрения дальнейшего выстраивания отношений с Японией, выглядит нота Советского правительства, врученная государственному департаменту США 1 февраля 1950 г., с требованием привлечь к суду императора Японии.

Советская нота была отклонена Вашингтоном, а её появление представитель государственного департамента США Макдермотт связал с желанием СССР отвлечь внимание мировой общественности от вопроса о репатриации японских военнопленных [6, с. 567]. В самой Японии требование СССР восприняли крайне враждебно и наоборот отклонение американцами советского требования восприняли с облегчением. В прессе писали: «Это требование русских оттолкнуло Японию от русских сильнее, чем что-либо другое», «»Многие японцы заявляют, что Россия не могла придумать ничего 


\section{Международные отношения / International Relations / № 3 / 2015}

лучше, если она намеревалась восстановить всех японцев против себя. Японцы вновь заявили, что требование России о предании суду императора не только восстановило массы против русских, но заставили японский народ с неприязнью относиться к местным коммунистам» [7, с. 568]. Именно такую реакцию предсказывал в своем донесении главнокомандующему Боннер Феллерс.

Подобные шаги советского правительства лишь играли на руку США, которые постоянно оказывали давление на правящую элиту Японии и проводили умелую пропаганду среди японского народа с целью недопущения сближения с СССР. США блестяще справились с задачей создать для СССР, а потом и России «японскую проблему».

13 марта 1951 года Государственный департамент США под руководством Дж. Ф. Даллеса закончил работу над проектом мирного договора с Японией $[8$, с. 50]. Договор должен был быть подписан на конференции в Сан-Франциско 4 сентября. В тексте договора говорилось, что Япония теряет суверенитет над частью Сахалина и Курильскими островами, но о том, что эти территории передаются Советскому Союзу, не было ни слова [8, с. 52]. В результате Советский союз не подписал мирный договор с Японией, а проблема Курильских островов до сих пор остается ключевым камнем преткновения в российско-японских отношениях.
В то время советское руководство находилось в эйфории от победы в Китае коммунистической партии, считая, что советско-китайский союз способен компенсировать отсутствие отношений с Японией [8, с. 55]. Как показало дальнейшее развитие событий, Китай оказался ненадежным союзником.

На сегодняшний день на территории Японии до сих пор располагаются американские военные базы, между Россией и Японией нет мирного договора, а сама Япония во внешней политике, в частности по отношению к России, остается зависимой от Соединенных Штатов Америки. В этой связи стоит отдать должное блестящим аналитическим и дипломатическим способностям американских специалистов, таким как Боннер Феллерс, которые сумели правильно оценить последствия тех или иных шагов для политики Соединенных Штатов.

В качестве заключительной иллюстрации стоит привести два факта. Боннер Феллерс перед войной с Японией занимался изучением японской ментальности и в 1937 году написал статью под названием «Психология японского солдата» [9, с. 13]. В СССР в 1937 году за «прояпонские настроения и шпионаж в пользу Японии» расстреляли талантливейшего филолога и этнографа Н.А. Невского, а также около 90 \% японоведов из Владивостока, академик Н.И. Конрад был отстранен от работы [2, с. 7].

\section{Библиография:}

1. Fellers B. Hirohito's struggle to surrender // Bonner Fellers : интернет-сайт. 2015. URL: http://www.bonnerfellers.com/ uploads/B.Fellers_Hirohitos_Struggle_to_Surrender_Foreign_Service_July_1947.pdf (дата обращения: 23.02.2015).

2. Панов А.Н. О Японии. Очерки и исследования дипломата. М.: ОЛМА Медиа Групп, 2014. 608 с.

3. Катасонова Е.Л. Японские военнопленные в СССР: большая игра великих держав. М.: Институт востоковедения РАН - «Крафт+», 2003. 432 с.

4. Японские военнопленные в СССР 1945 - 1956. Сборник документов / Составители В.А. Гаврилов, Е.Л. Катасонова. М.: МФД, 2013. 784 с.

5. Fellers B.F. Memorandum to the Commander-in-chief // Bonner Fellers : интернет-сайт. 2015. URL: http://www. bonnerfellers.com/uploads/B.Fellers_Memo_to_MacArthur_Oct_2_1945.pdf (дата обращения: 23.02.2015).

6. Заявление государственного департамента США по поводу советской ноты с требованием привлечь к суду японского императора (по каналам ТАСС) / Японские военнопленные в СССР: 1945-1956. Сборник документов // Составители В.А. Гаврилов, Е.Л. Катасонова. М.:МФД, 2013. С. 566-568.

7. О реакции в Японии на ноту советского правительства США, Англии и Китаю (по каналам ТАСС) / Японские военнопленные в СССР: 1945-1956. Сборник документов // Составители В.А. Гаврилов, Е.Л. Катасонова. М.: МФД, 2013. С. 568-569.

8. Панов А.Н. Клан Хатояма. Портрет семьи на фоне истории Японии. М.: ЗАО ОЛМА Медиа Групп, 2010.224 с.

9. Holden R. Saving the throne / Earlhamite. Winter 1998. P. 12-17.

10. Земсков В.Н. Начальный этап репатриации советских военнопленных и интернированных гражданских лиц (вторая половина 1944 г.) // Международные отношения.-2014.-2.-C. 272-289. DOI: 10.7256/2305-560X.2014.2.10749.

11. Анисимов Л.Н. Историко-правовой ракурс к проблеме мирного договора СССР (России) с Японией // Международные отношения.-2014.-2.-C. 290-298. DOI: 10.7256/2305-560X.2014.2.11296.

12. Манойло А.В. Сирийский тупик «Арабской весны». // Вестн. Моск. Ун-та. Сер. 12. Политические науки. 2013. C. 49-56.

13. Будаев А.В. Сравнительный анализ «мягкой силы» во внешней политике России и Бразилии. // Латинская Америка. 2014. № 4. С. 24-31. 


\section{История международных отношений / History of International Relations}

\section{References (transliterated):}

1. Fellers B. Hirohito's struggle to surrender // Bonner Fellers : internet-sait. 2015. URL: http://www.bonnerfellers.com/ uploads/B.Fellers_Hirohitos_Struggle_to_Surrender_Foreign_Service_July_1947.pdf (data obrashcheniya: 23.02.2015).

2. Panov A.N. O Yaponii. Ocherki i issledovaniya diplomata. M.: OLMA Media Grupp, 2014. $608 \mathrm{~s}$.

3. Katasonova E.L. Yaponskie voennoplennye v SSSR: bol'shaya igra velikikh derzhav. M.: Institut vostokovedeniya RAN «Kraft+», 2003. $432 \mathrm{~s}$.

4. Yaponskie voennoplennye v SSSR: 1945 - 1956. Sbornik dokumentov / Sostaviteli V.A. Gavrilov, E.L. Katasonova. M.: MFD, 2013. $784 \mathrm{~s}$.

5. Fellers B.F. Memorandum to the Commander-in-chief // Bonner Fellers : internet-sait. 2015. URL: http://www. bonnerfellers.com/uploads/B.Fellers_Memo_to_MacArthur_Oct_2_1945.pdf (data obrashcheniya: 23.02.2015).

6. Zayavlenie gosudarstvennogo departamenta SShA po povodu sovetskoi noty s trebovaniem privlech' k sudu yaponskogo imperatora (po kanalam TASS) / Yaponskie voennoplennye v SSSR: 1945-1956. Sbornik dokumentov // Sostaviteli V.A. Gavrilov, E.L. Katasonova. M.:MFD, 2013. S. 566-568.

7. O reaktsii v Yaponii na notu sovetskogo pravitel'stva SShA, Anglii i Kitayu (po kanalam TASS) / Yaponskie voennoplennye v SSSR: 1945-1956. Sbornik dokumentov // Sostaviteli V.A. Gavrilov, E.L. Katasonova. M.:MFD, 2013. S. 568-569.

8. Panov A.N. Klan Khatoyama. Portret sem'i na fone istorii Yaponii. M.: ZAO OLMA Media Grupp, 2010. 224 s.

9. Holden R. Saving the throne / Earlhamite. Winter 1998. P. 12-17.

10. Zemskov V.N. Nachal'nyi etap repatriatsii sovetskikh voennoplennykh i internirovannykh grazhdanskikh lits (vtoraya polovina 1944 g.) // Mezhdunarodnye otnosheniya.-2014.-2.-C. 272-289. DOI: 10.7256/2305-560X.2014.2.10749.

11. Anisimov L.N. Istoriko-pravovoi rakurs k probleme mirnogo dogovora SSSR (Rossii) s Yaponiei // Mezhdunarodnye otnosheniya.-2014.-2.-C. 290-298. DOI: 10.7256/2305-560X.2014.2.11296.

12. Manoylo A.B. Siriyskiy tupik «Arabskoy vesni». // Vestn. Mosk. Un-ta. Ser. 12. Politicheskie nauki. 2013. №6. S. 49-56.

13. Budaev A.B. Sravnitelniy analiz «myagkoy sili» vo vneshney politike Rossii i Brazilii. // Latinskaya Amerika. 2014 . № 4. S. 24-31. 